\title{
The Landscape of Poverty in Nigeria: A Spatial Analysis Using Senatorial Districts- level Data
}

\author{
Sowunmi F. A. ${ }^{1, *}$, Akinyosoye V. O. ${ }^{2}$, Okoruwa V.O. ${ }^{2}$, Omonona B. T. ${ }^{2}$ \\ ${ }^{1}$ Department of Economics, Lagos State University, Lagos, Nigeria \\ ${ }^{2}$ Department of Agricultural Economics, University of Ibadan Ibadan, Nigeria \\ fasowunmi@live.co.uk
}

\begin{abstract}
The study decomposes the Landscape of Poverty in Nigeria based on the significance of spatial contiguity using Senatorial Districts - level Data. The data used for the study were obtained from National Living Standard Survey and Core Welfare Indicators Questionnaire Survey conducted by National Bureau of Statistics in 2004 and 2006 respectively. Exp loratory spatial data analysis and spatial autocorrelation test were carried out on poverty incidence data.

Average national poverty rate of the Senatorial Districts (SD) was $56.0 \%$. Forty nine percent of the SD had poverty rate (PR) below the national average. The global Moran's I value obtained is strongly positive (0.6657), indicating that spillover of poverty exist among SD. The study revealed that $52 \%$ of the SD with significant spatial as sociation had low PR neighboured by low PR SD (Low-Low), 41\% of the SD with high PR were neighboured by high PR SD (High-High) and 7\% of SDs with low PR were surrounded by high PR SD (Low-High). The mean PR in high-high and low-low SDs was 82.6\% and 31.8\% respectively.

The study recommends that for a significant poverty reduction to be achieved in Nigeria, greater attention in terms of poverty alleviation strategies should be concentrated on the senatorial districts that constitute the hotspots of poverty.
\end{abstract}

Keywords Spatial Contiguity, Poverty Rate, Spatial Autocorrelation, Senatorial District

\section{Introduction}

The poverty phenomenon in Nigeria and other developing nations has attracted significant global attention since the 1990s. First, was the annual publication of the Human Development Report by the United Nations Development Programme (UNDP) which contains estimates of the Human Development Indices used to rank all the 177 Countries that make up the United Nations. The Human Development Index (HDI) is derived from social and economic indicators that are closely correlated with poverty. Human Development Index is a simple summary measure of three dimensions of human development concept: living a long and healthy life, being educated and having a decent standard of living. Thus it combines measures of life expectancy, school en rolment, literacy and income[1]. Since 2003, African Countries including Nigeria have ranked amongst the countries with the lowest HDI. In 2005, all the 27 Countries of the world with the lowest HDI were African Countries, Nigeria inclusive. These countries each has HDIs of less than 0.5 and when compared with figures of 0.968 for

* Corresponding author:

fasowunmi@live.co.uk (Sowunmi F. A.)

Published online at http://journal.sapub.org/economics

Copyright (C) 2012 Scientific \& Academic Publishing. All Rights Reserved
Iceland and Norway (the countries with the highest HDI) one will realized the enormity of the poverty problem in Nigeria and other lowly developed African Countries. Though the issues of poverty and low human development indices may not be peculiar to Africa, they are however more pronounced in the continent and the Nigeria situation is particularly worrisome because of the country's available natural resources and clement weather. Despite the conflicting statistical data on the incidence of poverty between government agency and international organization, there is undeniable fact that poverty situation in Nigeria is serious and deserves great attention. Specifically,[2] put the poverty rate of Nigeria at $54.4 \%$ while[1] and[3] reported $70.2 \%$ and $70 \%$ respectively.

Over the years a number of Poverty Reduction Strategy Programmes (PRSPs) has been initiated in Nigeria, this includes the recently designed National Economic Empowerment Development Strategies (NEEDS. In addition to the foregoing, a special Federal Govern ment institution to alleviate poverty in the country; the National Poverty Eradication Programmes (NAPEP) was created. These previously initiated PRSPs in the country along with many others initiated by the state governments appear only to have addressed the various manifestations of poverty, such as unemploy ment, lack of access to credit and functional rural and urban infrastructures, and gender inequality among others. 
While the above mentioned Poverty Reduction Strategy Programmes (PRSPs) were well intentioned, none had any significant, lasting, or sustainable positive effects on the people they were planned for[3],[4]. This can be attributed among others to the non consideration of the heterogeneous nature of poverty and spatial contiguity of geographical units in the design of PRSPs. Existing poverty studies treat a geographical unit, such as a local govern ment area, a state, or a senatorial district, or a county, as an independent isolated entity rather than as an entity surrounded by other geographic units with which it may interact is being considered by this study. Moreover, there is scarce information on spatial decomposition of poverty incidence among SD in Nigeria. Hence, the landscape of Poverty in Nigeria is investigated using Senatorial Districts (SDs) in Nigeria as geographic units.

Senatorial district is composed of Federal constituencies while federal constituency is made up of Local Government Areas. Each state is made up of three senatorial districts while the federal capital territory (Abuja) has one senatorial district. This means that each state in Nigeria is represented by three elected senators in the national assembly (upper legislative chamber). Delineation of the country into senatorial district by National Population Commission is based on population distribution. Apart from performing the legislative duties, senators are also task with the economic development of their respective senatorial district through lobby for sitting capital projects and judicious use of monthly constituency allowance meant for execution of projects in senatorial districts.

The study utilized spatial econometrics technique instead of the conventional econometrics methods. Spatial econometrics technique has the advantage of addressing the problem of spillover effect or spatial autocorrelation if present in the data set. According to[5], studies that ignore spatial autocorrelation (dependence) can produce biased results (coefficient estimates) and lead to ineffective and possibly counterproductive - recommendations for policies targeted at poverty alleviation.

The study identified the locations of senatorial districts with similar and dissimilar (outlier) pattern of poverty incidence. Knowing this will afford researchers to determine the factors that are specific to each of the identified groups. The finding of this study is expected to assist government in localizing poverty alleviation strategy of senatorial districts that exhib it similar spatial pattern of poverty.

\section{Conceptual Framework and Previous Literature}

\subsection{Conceptual Framework}

The philosophy behind this study is based on Tobler First Law of Geography:"everything is related to everything else, but near things are more related than distant things." Spatial clustering shows the similarity or dissimilarity of poverty in neighbouring units and spatial autocorrelation measures the strength of the spatial clustering[6],[7],[8],[9],[10]. Global spatial autocorrelation (Moran's I) analys is yields only one statistics to summarize the pattern of poverty in the whole study area. That is, global Moran's I assumes homogeneity of the study area (that poverty pattern is the same in all the senatorial districts). This is the limitation of global Moran's I. To localize the presence and magnitude of spatial autocorrelation, a measure such as Anselin's Local Indicators of Spatial Association (LISA) is necessary (see equation 7). This approach is most useful when, in addition to global trends in the entire sample of observations, there exist also pockets of localities exhibiting heterogeneous values that do not follow the global trend. This leads to identification of so-called hot spots -regions where the considered phenomenon is extremely pronounced across localities-as well of spatial outliers[11].

'Moran scatter plot' plots a variable of interest against spatial weighted component of that variable. This measure permits a more disaggregated view of the type of spatial autocorrelation that exists in a data. Local Indicators of Spatial Association[12] and Moran scatter plot[13] are valuable for gaining a "local" understanding of the extent and nature of spatial clustering in a geographical unit. LISA indicates significant spatial clustering for each location.

Moran scatter plot utilizes graph only to identify observations (extent of poverty) that are similar as well as different (outliers: neighbouring senatorial districts that has contrasting poverty rates) from their neighbours while formula is used in Local Moran's I to identify similarity or dissimilarity of poverty rates in neighbouring units. For each location (senatorial district), LISA values allow for the computation of its similarity with its neighbours and also to test its significance. Spatial association can be decomposed into four components, viz:

Senatorial districts with high concentration of poverty with similar neighbours: high-high. Also known as "hot spots".

- Senatorial districts with low concentration of poverty with similar neighbours: low-low. Also known as "cold spots".

- Senatorial districts with high concentration of poverty with low concentration of poverty neighbours: high-low. Potential "spatial outliers".

- Senatorial districts with low concentration of poverty with high concentration of poverty neighbours: low-high. Potential "spatial outliers".

- Senatorial districts with no significant local autocorrelation.

Reference[13] demonstrated that the slope of the regression line through the points in Moran scatter plot expresses the global Moran's I value. A strong positive statistic indicates positive spatial autocorrelation (clustering of like values). This means that most senatorial districts would be found in the high-high or low-low (first and third quadrants) areas of the country. 
A strong negative statistic indicates negative spatial autocorrelation suggests most senatorial districts with high (low) poverty concentration would be found in the vic inity of low (high) poverty senatorial districts (outliers).

\subsection{Review of Previous Liter ature}

Poverty is not only a state of existence but also a process with many dimensions and complexities. Generally, poverty has attracted a lot of attention from the academia and non-academia globally. Few recent studies are based on the premise that individuals and households with common characteristics sometimes are found clustered together either by choice or because they are constrained to co-locate by coercive operation of social, economic, geographic or political forces[14]. Identification of these households has been made possible through the advancement in spatial analytical techniques; which has also enables spatial pattern of poverty (concentration of poverty rates and outliers) to be quantified[15],[16],[17]. References[18],[19] showed that poverty rate in nearby locations are likely to be similar to one another, or error for the model in one area or location is correlated with the error terms in its neighboring locations; hence the need to pay attention to the structure of spatial dependence or autocorrelation in our data.

Reference[20] posited that knowing precisely where concentration of poverty exit will help the policy maker, social scientist and all other stake holders in continuing challenge of combating this fundamental threat (poverty) to well-being. Ignoring spatial autocorrelation will make it:

- impossible to measure the strength of spatial concentration of poverty.

- difficu lt to exp lain substantial variation in the incidence of poverty across senatorial districts.

In a study on the topography of poverty in US,[20] findings showed that $51.9 \%$ of the total counties belong to similar spatial concentration (low - low and high-high), whereas only $7.8 \%$ were categorized as being spatial outliers (high - low and low - high). The remaining $40.3 \%$ were neither. The categorization of spatial concentration into high or low poverty rate neighbourhood is in relationship with average national poverty rate. Most counties in US are found in the high-high and low-low subregions[14]. That is, the counties whose poverty rate is above (below) the average poverty rate are surrounded by counties with poverty rate above (below) average national poverty rate.

Reference[21] conducted a research on the application of a spatial regression model to analysis and poverty mapping in Ecuador; their results confirmed the significant effects of spatial autocorrelation variable that denotes the presence of clusters in the spatial distribution of poverty and the influence between neighbourhood households on the probability of being poor. A combination of processes (socioeconomic, political, demographic and geographic) operating in space over time has somehow conspired to partition countries into large regions of high and large regions of low poverty-with occasional "island" geographic units here and there that are very different from their neighbors[14].

Similarly,[22] in study on spatial clustering of rural poverty in Sri Lanka found that Divisional Secretariat (DS) divisions with a high percentage of poor households are found in four rural districts where agriculture is the main source of livelihood of the majority of households. The clustering of DS divisions of low poverty around major urban centres suggests that, in predominantly agricultural areas, poor people have only limited economic opportunities to escape poverty. They revealed that availability of and access to water and land resources are the major factors of spatial concentration of poverty in rural areas. In another study on spatial approach to social and political forces as a determinant of poverty in US, [5] stated that a positive and significant spatial dependence in the dependent variable (poverty rate) indicates that the poverty rate in a particular county is associated with poverty rates in surrounding counties/local government areas. According to them, the value of the spatial autocorrelation coefficient $(\rho=0.21$ in the model for all counties) obtained indicates that a 10 percentage point increase in the poverty rate in a county results in a $2 \%$ increase in the poverty rate in a neighbouring county. This is strong evidence that spillover effects exist between counties with respect to poverty. This finding is corroborated by[23]. They reasoned that poverty of a neighbourhood is tied to the fortunes of neighbouring areas: there are geographic spillovers in poverty reduction. Reducing poverty in particular neighbourhoods affects the poverty of neighbouring tracts.

\section{Methodology}

\subsection{Study Area}

The study covered the 109 Senatorial districts of Nigeria. According to section five subsections 71 and 72 of Nigeria's 1999 constitution, "the Independent National Electoral Commission shall divide each state of the federation into three Senatorial districts......... No Senatorial district or Federal constituency shall fall within more than one state, and the boundaries of each district or constituency shall be as contiguous as possible and be such that the number of inhabitants thereof is nearly equal to the population quota as is reasonably practicable." The fig. 1.0 shows the senatorial district map of Nigeria while table 1.0 gives the meaning of the senatorial districts' acrony ms. 


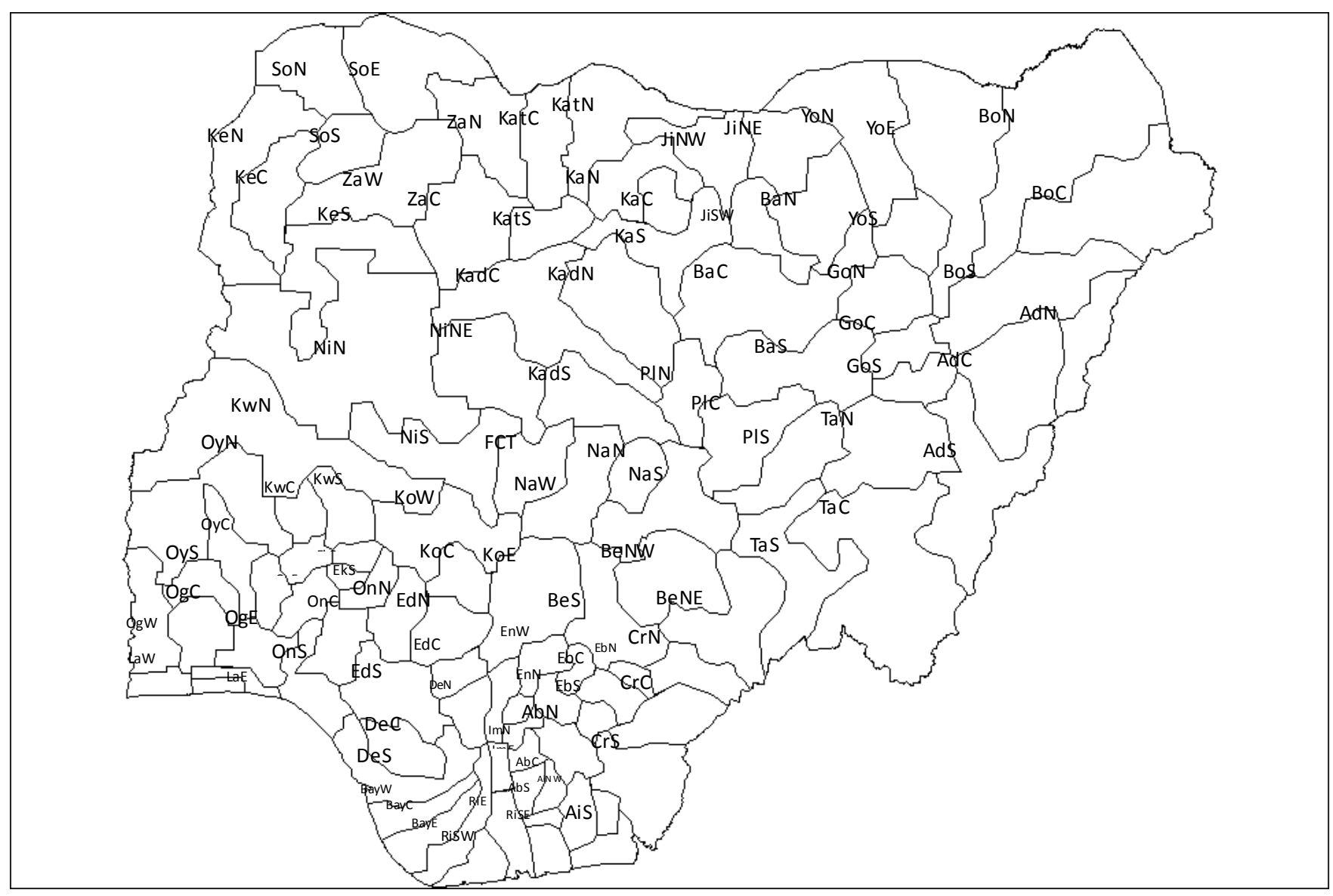

Source: Adapted from NBS (2007)

Figure 1. Senatorial District Map of Nigeria

\subsection{Methods of Data Analysis}

The study utilized descriptive and exploratory spatial data analyses (ESDA). The GIS software (ArcGIS 8.1) was used to ensure the compatibility of the senatorial district map with Geoda $0.9 .5 \mathrm{i}$

The most common measure of spatial autocorrelation, a statistic called global Moran's I[24],[25] is defined as follows:

$$
I_{\text {global }}=\left(\frac{n}{\sum_{i} \sum_{j \neq 1} w_{i j}}\right)\left(\frac{\sum_{i} \sum_{j \neq 1} w_{i j}\left(x_{i}-\bar{x}\right)\left(x_{j}-\bar{x}\right)}{\sum_{i}\left(x_{i}-\bar{x}\right)^{2}}\right)
$$

Where:

$i$ and $j$ index the area units of which there are $\mathrm{n}$,

wij is a spatial weight measure of contiguity defining the connection between area unit $i$ and area unit $j$.

$w$ is 1 if location $i$ is contiguous to location $j$ and 0 (zero) otherwise.

$x_{i}$ is the poverty rate for each senatorial district

$\bar{x}$ is the average poverty rate for 109 senatorial districts

Positive values of Moran's I suggest spatial clustering of similar values across geo - space. A significant negative value (infrequent in the social sciences) indicates that neighbouring values are more dissimilar than expected by chance, that is high values are frequently found in the vicinity of low values.. The I statistic is similar to the familiar Pearsonian product-moment correlation coefficient, however, the maximum and minimum possible values of Moran's I are not constrained to lie in the $(-1,1)$ range[26],[27].

The expected value and variance of Moran's I for a sample of size $n$ could be calculated according to the assumed pattern of the spatial data distribution[24].

For the assumption of a normal distribution:

$$
\begin{gathered}
E_{n}(I)=-\frac{1}{(n-1)} \\
\operatorname{Var}_{n}(I)=\frac{n^{2} w_{1}-n w_{2}+3 w_{0}^{2}}{w_{0}^{2}\left(n^{2}-1\right)}-E_{n}^{2}(I)
\end{gathered}
$$

For the assumption of rando $m$ dis tribution:

$$
E_{r}(I)=-\frac{1}{(n-1)}
$$

$\operatorname{VAR}_{r}(I)=$

$$
\frac{n\left(\left(n^{2}-3 n+3\right) w_{1}-n w_{2}+3 w_{0}^{2}\right)-K_{2}\left(\left(n^{2}-n\right) w_{1}-2 n w_{2}+6 w_{0}^{2}\right)}{w_{0}^{2}(n-1)(n-2)(n-3)}-E_{r}^{2}(I)
$$

where: $K_{2}=\frac{n \sum_{i}^{n}\left(x_{i}-\bar{x}\right)^{4}}{\left(\sum_{i}^{n}\left(x_{i}-\bar{x}\right)^{2}\right)}, w_{0}=\sum_{i}^{n} \sum_{j}^{n} w_{i j}$, 
Table 1. Senatorial Districts' Ident ity

\begin{tabular}{|c|c|c|c|c|c|c|c|}
\hline Senatorial District & ID & Senatorial District & ID & Senatorial District & ID & Senatorial District & ID \\
\hline Abia Central & $\mathrm{AbC}$ & Cross River South & $\mathrm{CrS}$ & Kaduna South & KadS & Ogun West & $\mathrm{OgW}$ \\
\hline Abia North & $\mathrm{AbN}$ & Delta Central & $\mathrm{DeC}$ & Kano Central & $\mathrm{KaC}$ & Ondo Central & OnC \\
\hline Abia South & $\mathrm{AbS}$ & Delta North & DeN & Kano North & $\mathrm{KaN}$ & Ondo West & OnW \\
\hline Adamawa Central & $\overline{A d C}$ & Delta South & $\mathrm{DeS}$ & Kano South & $\mathrm{KaS}$ & Ondo East & OnE \\
\hline Adamawa North & $\mathrm{AdN}$ & Ebonyi Central & $\mathrm{EbC}$ & Katsina Central & KatC & Osun Central & OsC \\
\hline Adamawa South & $\mathrm{AdS}$ & Ebonyi North & $\mathrm{EbN}$ & Katsina North & KatN & Osun East & OsE \\
\hline Akwa Ibom North West & AiNW & Ebonyi South & EbS & Katsina South & KatS & Osun West & OsW \\
\hline Akwa Ibom North East & AiNE & Edo Central & $\mathrm{EdC}$ & Kebbi Cental & $\mathrm{KeC}$ & Oyo Central & $\mathrm{OyC}$ \\
\hline Akwa Ibom South & AiS & Edo North & $\mathrm{EdN}$ & Kebbi North & $\mathrm{KeN}$ & Oyo North & OyN \\
\hline Anambra Central & $\mathrm{AnC}$ & Edo South & EdS & Kebbi South & $\mathrm{KeS}$ & Oyo South & OyS \\
\hline Anambra North & $\mathrm{AnN}$ & Ekiti Central & $\mathrm{EkC}$ & Kogi West & KoW & Plateau Central & $\mathrm{PlC}$ \\
\hline Anambra South & AnS & Ekiti North & $\mathrm{EkN}$ & Kogi Central & $\mathrm{KoC}$ & Plateau North & PIN \\
\hline Bauchi Central & $\mathrm{BaC}$ & Ekiti South & EkS & Kogi East & $\mathrm{KoE}$ & Plateau South & P1S \\
\hline Bauchi North & $\mathrm{BaN}$ & Enugu East & $\mathrm{EnE}$ & Kwara Centarl & $\mathrm{KwC}$ & Rivers East & $\mathrm{RiE}$ \\
\hline Bauchi South & $\mathrm{BaS}$ & Enugu North & $\mathrm{EnN}$ & Kwara North & $\mathrm{KwN}$ & Rivers South East & RiSE \\
\hline Bayelsa Central & BayC & Enugu West & EnW & Kwara South & KwS & Rivers South West & RiSW \\
\hline Bayelsa East & BayE & Gombe Central & $\mathrm{GoC}$ & Lagos central & $\mathrm{LaC}$ & Sokoto East & SoE \\
\hline Bayelsa West & BayW & Gombe North & GoN & Lagos East & $\mathrm{LaE}$ & Sokoto North & SoN \\
\hline Benue North East & $\mathrm{BeNE}$ & Gombe South & GoS & Lagos West & $\mathrm{LaW}$ & Sokoto South & SoS \\
\hline Benue North West & BeNW & Imo East & $\operatorname{ImE}$ & Nassarawa North & $\mathrm{NaN}$ & Taraba Central & $\mathrm{TaC}$ \\
\hline Benue South & $\mathrm{BeS}$ & Imo North & $\operatorname{ImN}$ & Nassarawa South & $\mathrm{NaS}$ & Taraba North & $\mathrm{TaN}$ \\
\hline Borno Central & $\mathrm{BoC}$ & Imo West & $\operatorname{ImW}$ & Nassarawa Central & $\mathrm{NaC}$ & Taraba South & $\mathrm{TaS}$ \\
\hline Borno North & $\mathrm{BoN}$ & Jigawa North East & JiNE & Niger East & $\mathrm{NiE}$ & Yobe East & YoE \\
\hline Borno South & $\mathrm{BoS}$ & Jigawa North West & JiNW & Niger North & $\mathrm{NiN}$ & Yobe North & YoN \\
\hline Borno South & $\mathrm{BoS}$ & Jigawa South West & JiSW & Niger South & $\mathrm{NiS}$ & Yobe South & YoS \\
\hline Cross River Central & $\mathrm{CrC}$ & Kaduna Central & $\mathrm{KadC}$ & Ogun Central & $\mathrm{OgC}$ & Zamfara Central & $\mathrm{ZaC}$ \\
\hline Cross River North & $\mathrm{CrN}$ & Kaduna North & KadN & Ogun East & $\mathrm{OgE}$ & Zamfara North & $\mathrm{ZaN}$ \\
\hline Zamfara West & $\mathrm{ZaW}$ & & & & & & \\
\hline FCT & $\mathrm{AbJ}$ & & & & & & \\
\hline
\end{tabular}

Source: Survey Data, 2010

$$
w_{1}=\frac{1}{2} \sum_{i}^{n} \sum_{j}^{n}\left(w_{i j}+w_{j i}\right)^{2}, \quad w_{2}=\sum_{i}^{n}\left(w_{i}+w_{j}\right)^{2}
$$

$w_{i}$. and $w_{\cdot i}$ are the sum of the row $i$ and column $i$ of the weight matrix respectively.

The test of the null hypothesis that there is no spatial autocorrelation between observed values over the $n$ locations can be conducted on the bas is of the standardized statistics as follows:

$$
Z(d)=\frac{I(d)-E(I)}{\sqrt{\operatorname{VAR}(I)}}
$$

Moran's I is significant and positive when the observed values of locations within a certain distance $(d)$ tend to be similar, negative when they tend to be dissimilar, and approximately zero when the observed values are arranged randomly and independently over space.

Spatial analysis (Local indicator of Spatial Association
Indices, Local indicator of Spatial Association Cluster Map, Local indicator of Spatial Ass ociation Significance Map and Moran scatter plot) is employed to identify the senatorial districts with similar spatial pattern of poverty incidence. The analys is is carried out whether spatial autocorrelation is significantly present in the geo-referenced data set or not. Local Moran's I is computed using the formula below:

$$
I_{\text {local }}=\frac{\sum_{i} w_{i j}\left(x_{i}-\bar{x}\right)\left(x_{j}-\bar{x}\right)}{\sum_{i}\left(x_{i}-\bar{x}\right)^{2}}
$$

The result from the spatial analysis above (LISA) identifies the senatorial districts with similar pattern of spatial distribution of poverty incidence as well as outliers (high - high, low - low, low - high and high - low). The significance or non significance of spatial autocorrelation is a prerequisite for the choice of corrective measure. 


\section{Empirical Results and Discussion}

The study showed a low poverty incidence (\%) in the southern part of the country which ranges from 8.1 to 36.9 . In the north central, the poverty incidence ranges fro $\mathrm{m} 55.4 \%$ to $78.1 \%$. The core north which (comprises of north west and north east) has the highest poverty incidence ranging fro $\mathrm{m}$ $78.4 \%$ in Zamfara central to $97.7 \%$ in Jigawa northeast. Generally, the study revealed an average poverty rate of $56.04 \%$ among the 109 senatorial districts (see figure 1.1). Federal Capital Territory, Kaduna central, Kano central and Borno central are the three senatorial districts in the north that the poverty rates are substantially lower than the national poverty rate. This may be attributed to the location of state capitals (seat of government) in these senatorial districts where basic infrastructures are concentrated.

Moreover, the three senatorial districts in Lagos state (Lagos east, Lagos west and Lagos central), one in Edo state (Edo central) and Cross - River (Cross - River north) have the poverty rates higher than the national poverty rate in the south. The poverty rates in the six geopolitical zones corroborate the findings above (see figure 1.2). Specifically, the average poverty rate in the southeast is the lowest $(29.9 \%)$, while average poverty rates of southsouth and southwest are $39.8 \%$ and $37.9 \%$ respectively. The northwest geopolitical zone has the highest average poverty rate $(77.6 \%)$; this is followed by northeast $(74.5 \%)$ and northcentral $(68.1 \%)$. The high average poverty rates in the northern geopolitical zones may be attributed to long standing lags in provision of health, education and other social services resulting in proportionately more poor in the north[28]. He reasoned that the southern zone has most of the industries and many export crops while the northern zone is largely rural and agricultural with a fragile agro - climatic environment and a different socioeconomic history.

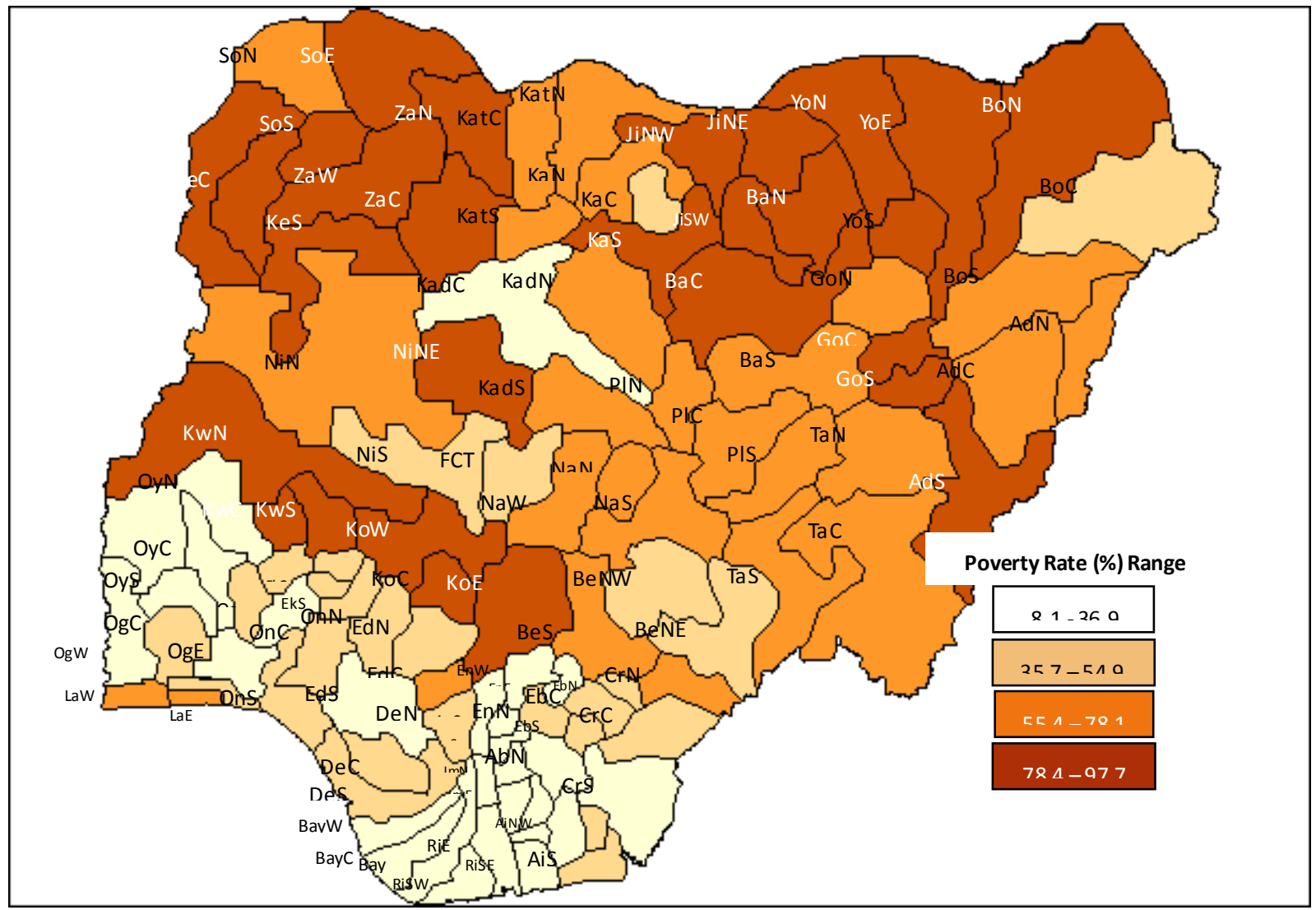

Source: Result of Data Analyzed (2010)

Figure 1.1. Map of Poverty Rates based on 109 Senatorial Districts 


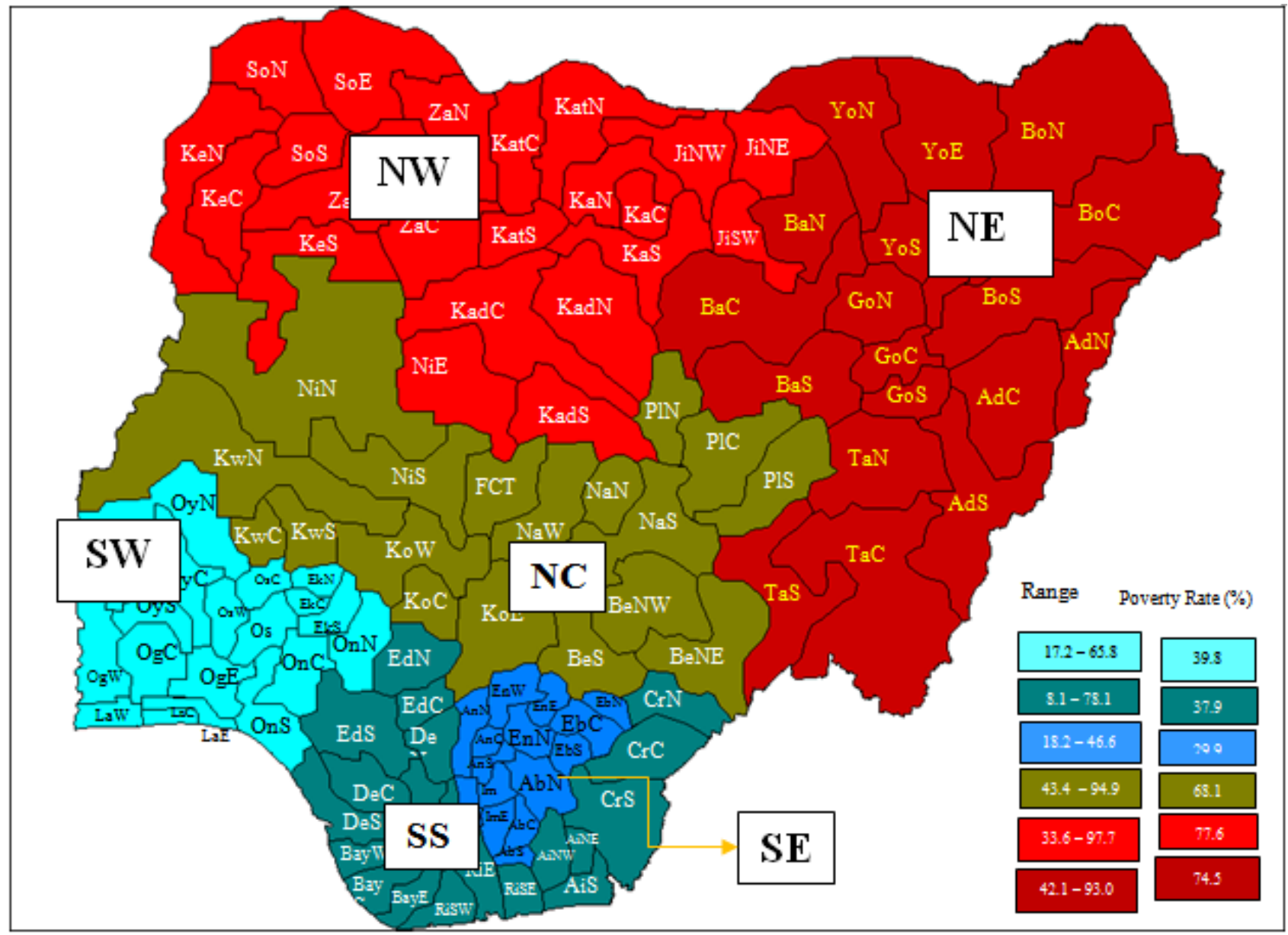

Source: Result of Data Analyzed (2010)

Figure 1.2. Map of Poverty Rates among the Geopolitical Zones

Furthermore, appro ximately $49 \%$ of the senatorial districts (53 SD) have poverty rates below the average national poverty rate $(56.0 \%)$. The study showed that out of the 53 senatorial districts that the poverty rates are below the national poverty line, $87 \%$ is in the southern part of the country while 13\% (Borno central, Kano central, Kaduna central, Niger south, FCT, Benue northwest and Benue northeast) is located in the northern part of the country. Also, $91 \%$ of the SDs having poverty rates above the national poverty rate is located in the north while $9 \%$ (Lagos east, Lagos west, Lagos central, Edo central and Cross - River north) is found in the south (see figure 1.3).

Figure 1.4 shows that $30 \%$ of the senatorial districts in northeast, $34 \%$ in northwest and $27 \%$ in northcentral geopolitical zones have poverty rates above the national poverty rate $(56.0 \%)$. Conversely, $4 \%$ of the senatorial districts in southsouth, $0 \%$ in the southeast and $5 \%$ in the southwest have poverty rates above the national poverty rate. Among the geopolitical zones, southsouth has the highest number of senatorial districts with poverty rates below the national poverty rate $(38 \%)$. This is followed by southeast and southwest that shared the same percentage (28\%).

The result of the analysis showed that there is positive spatial autocorrelation $(0.665)$ in poverty incidence across Nigeria (see figure 1.5). The diagnostics for spatial dependence using a contiguity-based spatial weights matrix also revealed that the spillover effect is not only present but significant $(p<0.001)$. The figure below shows the Moran scatter plot of poverty rates for the senatorial districts in Nigeria. Reference[13] demonstrated that the slope of the regression line through these points expresses the global Moran's I value as shown in figure 1.5 below.

Figure 1.5 below shows that most senatorial districts are found in the high - high (47) or low - low (43) neighbourhoods in the country. Specifically, the upper right quadrant of the Moran Scatterplot shows the SD with above average poverty rate that also share boundaries with neighbouring SD that have above national average value of poverty rate (high-high). The lower left quadrant shows SD with below average poverty rate values and neighbours also with below national average values (low-low). The lower right quadrant displays SD with above average poverty rate surrounded by SD with below average values (high-low), and the upper left quadrant contains the reverse (low-high). The SD in the lower right and upper left quadrants are the outliers. 


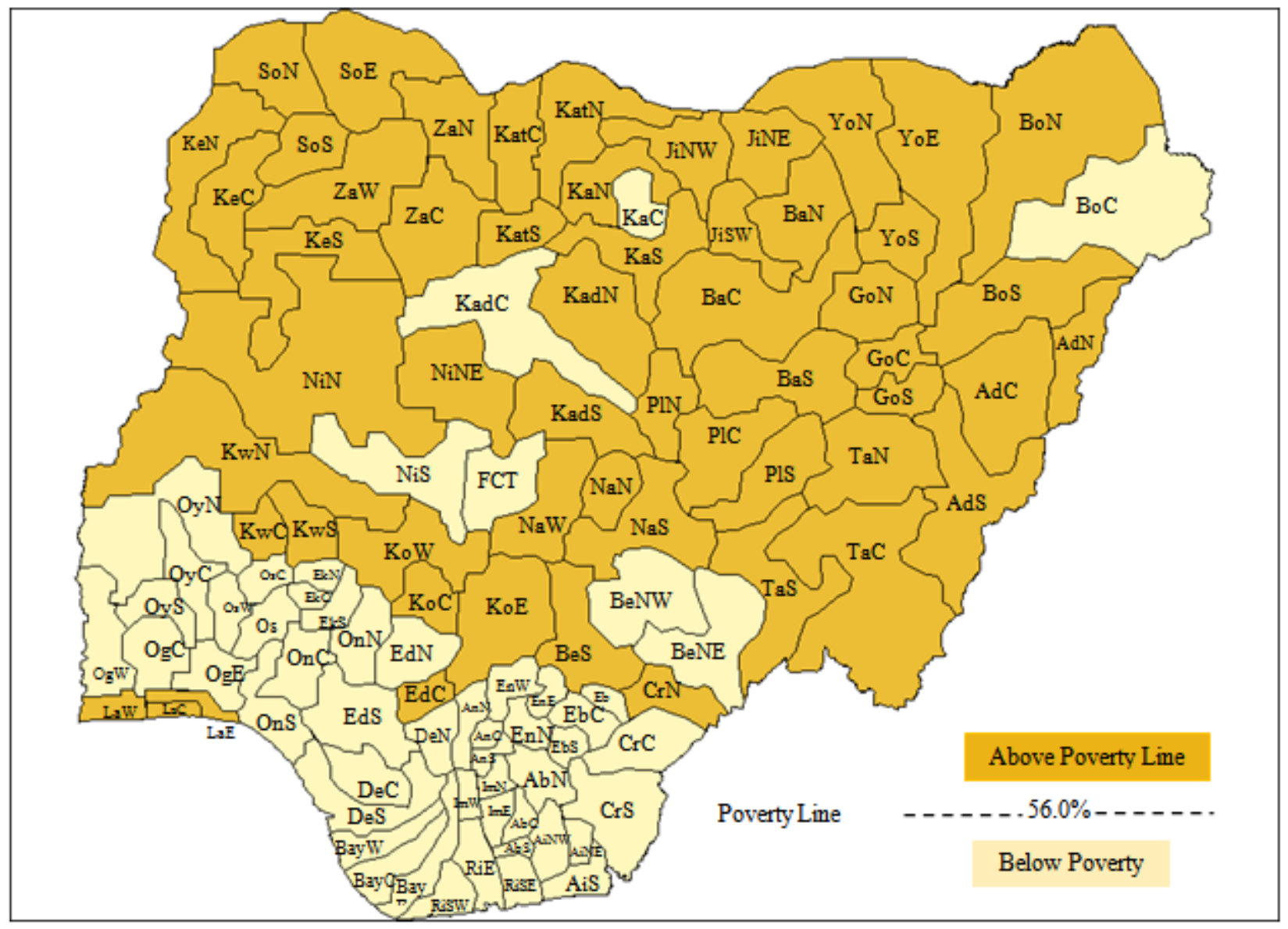

Source: Result of Data Analyzed (2010)

Figure 1.3. Map of Poverty Line among 109 Senat orial Districts

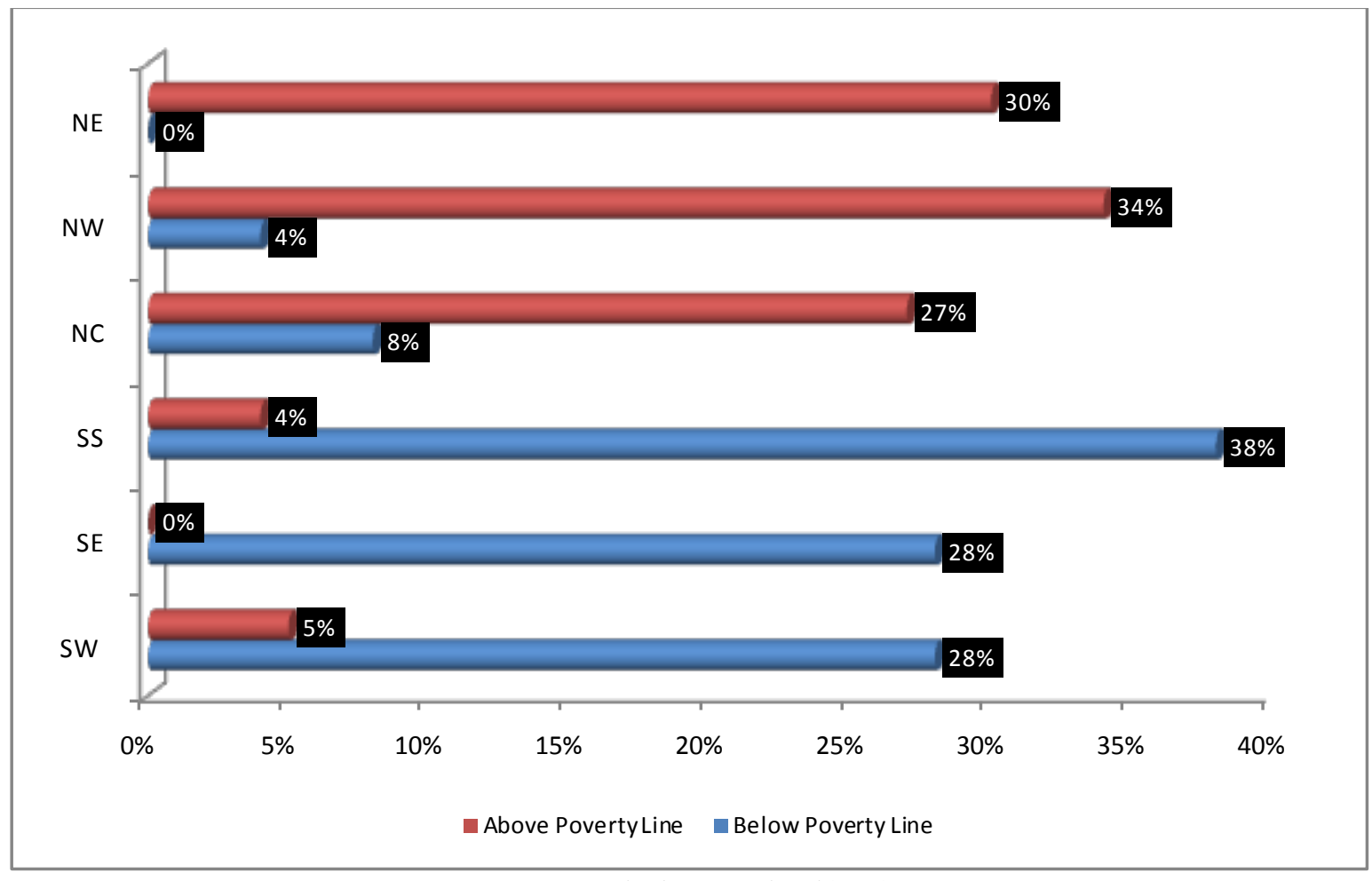

Sou rce: Result of Data Analyzed(2010)

Figure 1.4. Distribution Poverty Line among Senatorial Districts 
Table 1.1. Diagnostics for Spatial DependenceFOR WEIGHT MATRIX : koloqueenPIA.GAL (row-standardized weights)

\begin{tabular}{|c|c|c|c|}
\hline TEST & MI/DF & VALUE & PROB \\
\hline Moran's I (error) & 0.125539 & 3.3653048 & 0.0007647 \\
\hline Lagrange Multiplier (lag) & 1 & 11.677104 & 0.0006327 \\
\hline Robust LM (lag) & 1 & 7.6509946 & 0.0056741 \\
\hline Lagrange Multiplier (error) & 1 & 4.0263889 & 0.0447937 \\
\hline Robust LM (error) & 1 & 0.0002795 & 0.9866617 \\
\hline
\end{tabular}

Source: Result of Data Analyzed (2010)

The study did not only reveal the significant presence of spatial dependence but also the type of spatial dependence that is more likely, using the robust Lagrange Multiplier indicators[13]. The table 1.1 shows that spatial lag is the type of spatial dependence present in poverty incidence in Nigeria. The value for robust Lagrange multiplier (lag) is high and significant $(\mathrm{p}<0.01)$. This means that poverty incidence in one SD is not only influenced by factors within but also by the poverty incidence in nearby SD. That is, proximity of senatorial districts in fluences the poverty rates. The imp lication of this result is that spatial dimension has to be given consideration in any causal relationship between poverty rate and factors influencing it.

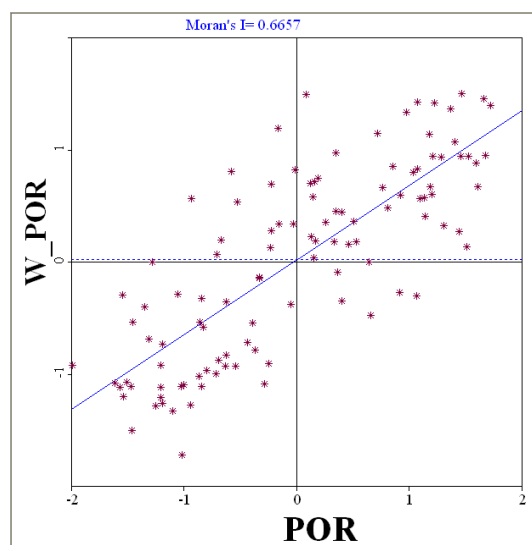

Sou rce: Result of Data Analyzed(2010)

Figure 1.5. Moran Scatter Plot of Poverty Incidence

\subsection{Loc ation of Senatorial Dis tricts with Similar Pattern of Poverty Inci dence.}

The result obtained from Local Indicator of Spatial Association (LISA) revealed that out of 90 senatorial districts that have similar spatial pattern of poverty incidence (high-high and low-low), 51 have similar spatial patterns that are statistically significant (at $\mathrm{p} \leq 5 \%$, see table 1.2 below). The high - high constitutes the senatorial districts with more pronounced poverty incidence as well as their neighbouring SD.

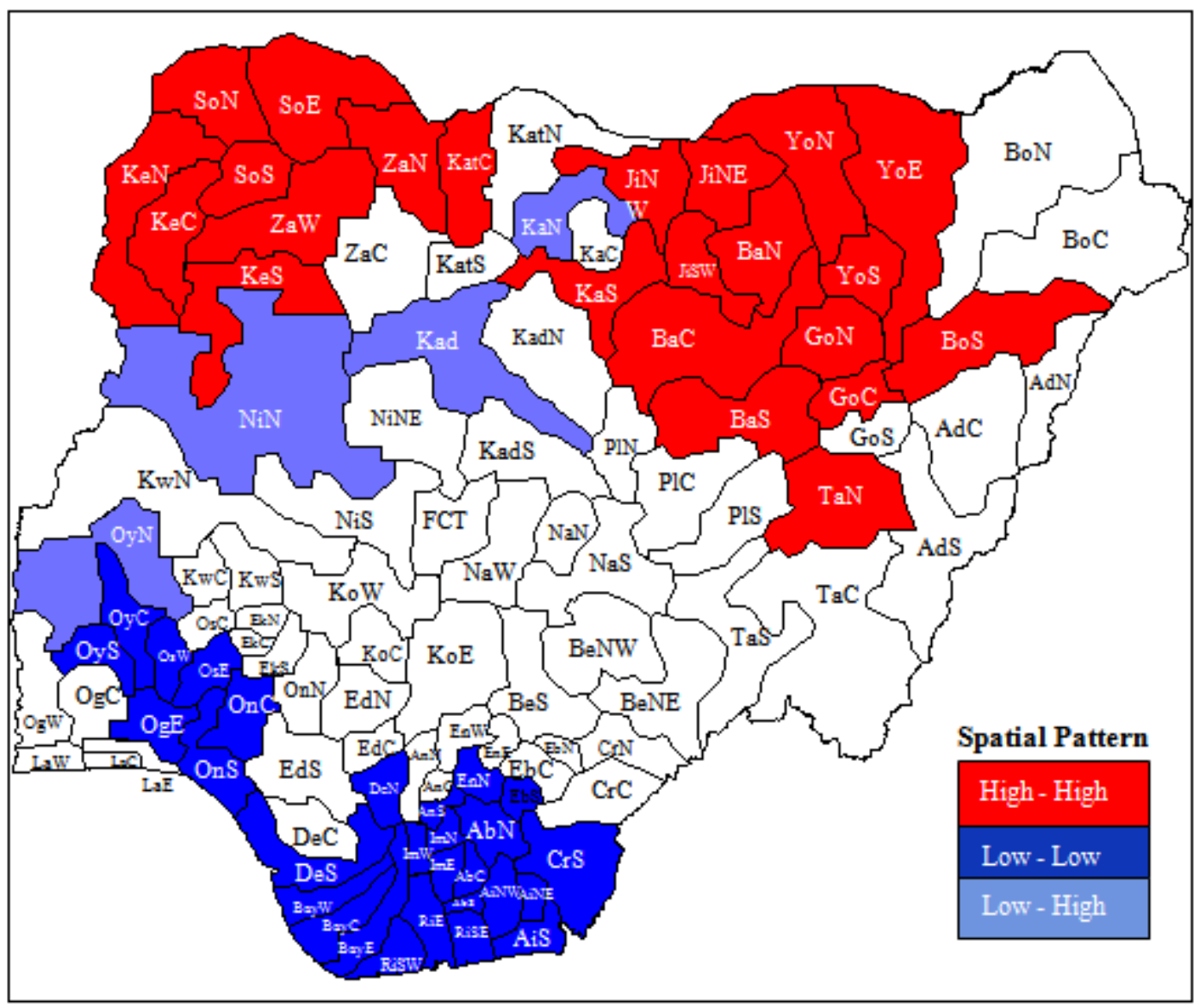

Sou rce: Result of Analyzed Data (2010)

Figure 1.6. Local Indicat or of Spatial Association (LISA) Map for Significant SpatialPattern 
Table 1.2. Local Indicat or of Spatial Association (LISA) Groupings of Senatorial Districts

\begin{tabular}{|c|c|c|c|}
\hline LISA Grouping & Total & Sig. (at least 0.05) & Not Sig. \\
\hline Low - Low & 43 & 28 & 15 \\
\hline High - High & 47 & 23 & 24 \\
\hline Low - High & 13 & 4 & 9 \\
\hline High - Low & 6 & NA & 6 \\
\hline
\end{tabular}

Source: Result of Data Analyzed (2010)

Out of 19 outlier (dissimilar pattern: High-low and low-high), $4 \mathrm{SD}$ are significant (see the figure 1.6 above). The part of the figure with white pattern shows the SD patterns' that are not statistically significant $(p>0.05)$. The significant cluster locations identify locations with a high correlation to the weighted average of the values of its neighbours. Figure 1.6 shows the high poverty rates SD bordered by high poverty SD are concentrated in the north part of the country while the low-low SD are concentrated in the south. The high concentration of poverty incidence in the northern part of the country may be attributed to low level of education and poor infrastructural facilities among other factors. Few exceptions are Borno central, Kano central, Kaduna central and Abuja (Low-high) in the north while Lagos state senatorial districts are found in the south (see figure 1.6).

High poverty incidence in Lagos state senatorial districts unlike other senatorial districts in the southern part of Nigeria may not be unconnected with high level of rural-urban migration which makes the available infrastructures to be overstretched. Lagos state being the commercial nerve center of Nigeria attracts the poor from all parts of the country, believing that their relocation to Lagos will improve their standard of living. Knowing the factors responsible for the more pronounced incidence of poverty in the red-shaded senatorial districts is important in order to come up with workable poverty reduction strategy in Nigeria.

The categorization of senatorial districts to spatial patterns was based on indicator (CL POR) for the type of cluster. It takes the value of $\mathbf{1}$ for high-high, $\mathbf{2}$ for low-low, $\mathbf{3}$ for low-high and 4 for high-low[9]. The categorization as reported by Geoda 0.9.5.i is shown in table 1.4[9],[10]

Table 13. Spatial Pattern Distribution of Poverty Incidence

\begin{tabular}{|c|c|c|c|}
\hline Low - High & Low - Low & High - High & H - L (NS) \\
\hline Kaduna Central $^{\mathrm{SC}}$ & Abia Central $^{\mathrm{SC}}$ & Bauchi Central $^{\mathrm{SC}}$ & Cross river North ${ }^{\mathrm{NS}}$ \\
\hline Kano North ${ }^{\mathrm{SC}}$ & Abia North ${ }^{\mathrm{SC}}$ & Bauchi North $^{\mathrm{SC}}$ & Edo Central $^{\mathrm{NS}}$ \\
\hline Niger North ${ }^{\mathrm{SC}}$ & Abia South ${ }^{\mathrm{SC}}$ & Bauchi South $^{\mathrm{SC}}$ & Kaduna South $^{\text {NS }}$ \\
\hline Oyo North ${ }^{\mathrm{SC}}$ & Akwa ibom Northeast ${ }^{\mathrm{sc}}$ & Borno South ${ }^{\mathrm{SC}}$ & Lagos Central $^{\mathrm{NS}}$ \\
\hline Abuja $^{\text {NS }}$ & Akwa Ibom Northwest ${ }^{\text {SC }}$ & Gombe Central $^{\mathrm{SC}}$ & Lagos East $^{\mathrm{NS}}$ \\
\hline Benue Northeast ${ }^{N S}$ & Akwa Ibom South ${ }^{\mathrm{SC}}$ & Gombe North ${ }^{\mathrm{SC}}$ & Lagos West ${ }^{\mathrm{NS}}$ \\
\hline Benue Northwest ${ }^{\text {NS }}$ & Anambra South ${ }^{\mathrm{SC}}$ & Jigawa Northeast $^{\mathrm{SC}}$ & \\
\hline Borno Central $^{\mathrm{NS}}$ & Bayelsa Central $^{\text {SC }}$ & Jigawa Northwest $^{\mathrm{SC}}$ & \\
\hline Edo North ${ }^{\mathrm{NS}}$ & Bayelsa East $^{\text {sC }}$ & Jigawa Southwest ${ }^{\mathrm{SC}}$ & \\
\hline Ekiti North $^{\text {NS }}$ & Bayelsa West ${ }^{\mathrm{SC}}$ & Kano South $^{\text {SC }}$ & \\
\hline Kano Central $^{\mathrm{NS}}$ & Cross river South ${ }^{\mathrm{SC}}$ & Katsina Central ${ }^{\mathrm{SC}}$ & \\
\hline Niger South ${ }^{\text {NS }}$ & Delta North ${ }^{\text {SC }}$ & Kebbi Central ${ }^{\mathrm{SC}}$ & \\
\hline \multirow[t]{12}{*}{ Plateau North ${ }^{\text {NS }}$} & Delta South $^{\text {SC }}$ & Kebbi North ${ }^{\mathrm{SC}}$ & \\
\hline & Ebonyi South $^{\mathrm{SC}}$ & Kebbi South ${ }^{\mathrm{SC}}$ & \\
\hline & Enugu North ${ }^{\mathrm{SC}}$ & Sokoto East ${ }^{\mathrm{SC}}$ & \\
\hline & Imo East ${ }^{\mathrm{sC}}$ & Sokoto North ${ }^{\mathrm{SC}}$ & \\
\hline & Imo North $^{\mathrm{SC}}$ & Sokoto South ${ }^{\mathrm{SC}}$ & \\
\hline & $\mathrm{Imo} \mathrm{West}^{\mathrm{SC}}$ & Taraba North $^{\mathrm{SC}}$ & \\
\hline & Ogun East ${ }^{\mathrm{SC}}$ & Yobe East $^{\mathrm{SC}}$ & \\
\hline & $\mathrm{Ondo}^{\mathrm{SC}}$ & Yobe North ${ }^{\mathrm{SC}}$ & \\
\hline & Ondo Central $^{\text {SC }}$ & Yobe South $^{\mathrm{SC}}$ & \\
\hline & Osun East ${ }^{\mathrm{SC}}$ & Zamfara North ${ }^{\mathrm{SC}}$ & \\
\hline & Osun West ${ }^{\mathrm{SC}}$ & Zamfara West ${ }^{\mathrm{sC}}$ & \\
\hline & Oyo Central $^{\mathrm{SC}}$ & Adamawa Central $^{\mathrm{NS}}$ & \\
\hline
\end{tabular}




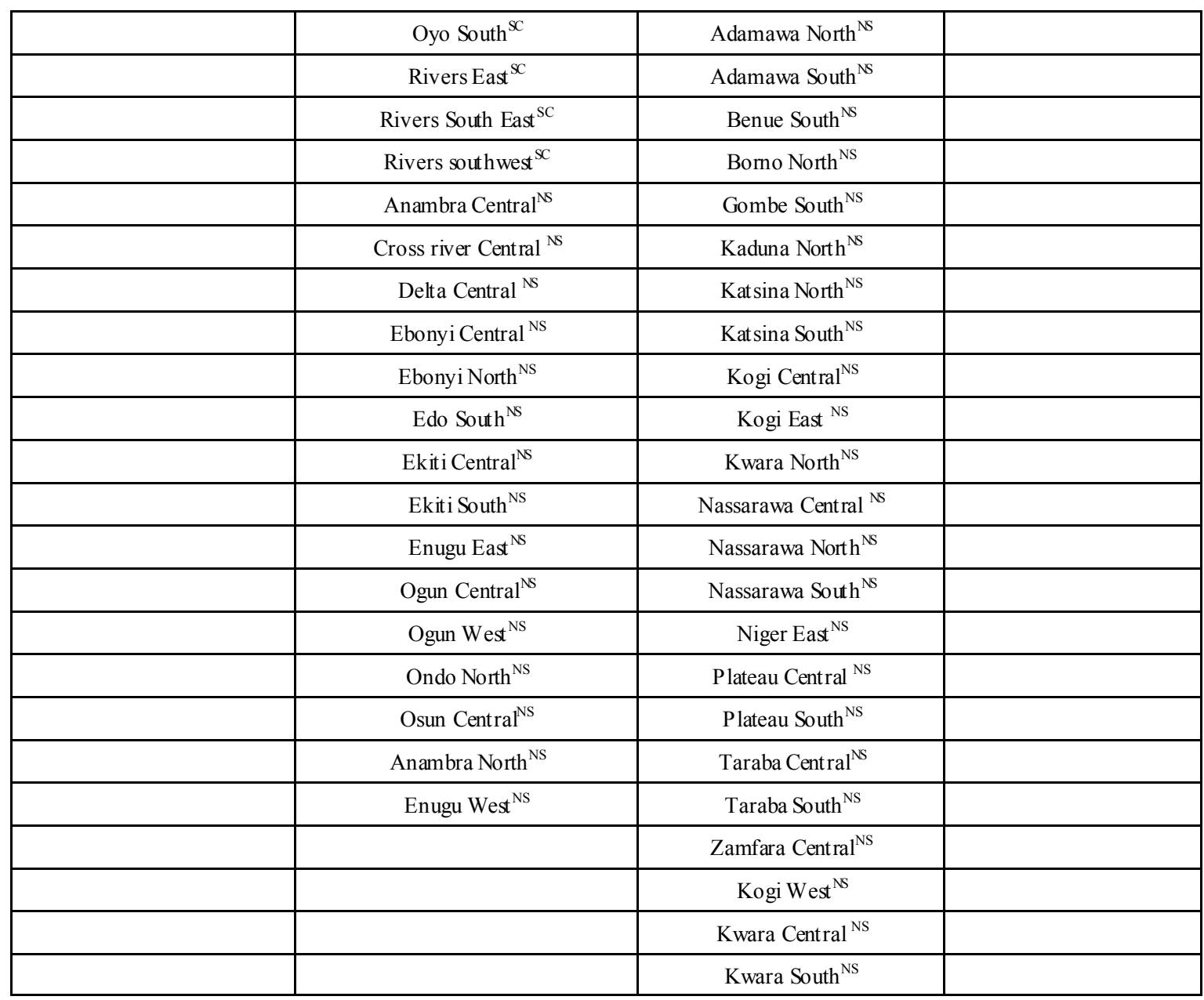

Note: NS means not significant spatial pattern, SC means significant spatial pattern

Table 1.4. LISA Indices and Cluster Type for Each Senatorial District

\begin{tabular}{|c|c|c|c|c|c|c|c|c|c|c|c|}
\hline $\begin{array}{l}\text { Senatoria } \\
1 \text { Districts } \\
\end{array}$ & $\begin{array}{c}\text { LISA } \\
\text { Indices } \\
\end{array}$ & $\begin{array}{l}\text { Cluste } \\
\text { r Type }\end{array}$ & P - Value & $\begin{array}{c}\text { Senatorial } \\
\text { Districts }\end{array}$ & $\begin{array}{l}\text { LISA } \\
\text { Indices }\end{array}$ & $\begin{array}{l}\text { Cluste } \\
\text { r Type }\end{array}$ & P - Value & $\begin{array}{c}\text { Senatorial } \\
\text { Districts }\end{array}$ & $\begin{array}{l}\text { LISA } \\
\text { Indices }\end{array}$ & $\begin{array}{l}\text { Cluste } \\
\text { r Type }\end{array}$ & P - Value \\
\hline $\begin{array}{c}\text { Borno } \\
\text { Central } \\
\end{array}$ & $\begin{array}{c}-0.46422 \\
3 \\
\end{array}$ & 0 & $0.138^{\mathrm{ns}}$ & $\begin{array}{c}\text { Bayelsa } \\
\text { Central } \\
\end{array}$ & 1.755446 & 2 & $\begin{array}{c}0.004^{* *} \\
* \\
\end{array}$ & $\begin{array}{l}\text { Taraba } \\
\text { North } \\
\end{array}$ & 0.085121 & 1 & $0.04 * *$ \\
\hline $\begin{array}{l}\text { Sokoto } \\
\text { North }\end{array}$ & 0.13299 & 1 & $\begin{array}{c}0.002^{* *} \\
* \\
\end{array}$ & $\begin{array}{c}\text { Bayelsa } \\
\text { East }\end{array}$ & 1.566994 & 2 & $\begin{array}{c}0.002 * * \\
*\end{array}$ & $\begin{array}{l}\text { Plateau } \\
\text { South }\end{array}$ & 0.18165 & 0 & $0.218^{\mathrm{ns}}$ \\
\hline $\begin{array}{c}\text { Sokoto } \\
\text { East }\end{array}$ & 1.375078 & 1 & $0.036^{* *}$ & $\begin{array}{c}\text { Rivers } \\
\text { southwest }\end{array}$ & 1.461355 & 2 & $0.034 * *$ & $\begin{array}{l}\text { Plateau } \\
\text { Central }\end{array}$ & 0.093344 & 0 & $0.234^{\mathrm{ns}}$ \\
\hline $\begin{array}{l}\text { Kebbi } \\
\text { North }\end{array}$ & 1.399922 & 1 & $0.024 * *$ & Imo West & 1.765913 & 0 & $0.07^{\mathrm{ns}}$ & $\begin{array}{l}\text { Bauchi } \\
\text { South }\end{array}$ & 0.456214 & 1 & $0.05^{* *}$ \\
\hline $\begin{array}{c}\text { Kebbi } \\
\text { Central } \\
\end{array}$ & 1.737993 & 1 & $\begin{array}{c}0.002 * * \\
* \\
\end{array}$ & $\begin{array}{c}\text { Rivers } \\
\text { East }\end{array}$ & 1.440714 & 2 & $\begin{array}{c}0.004^{* *} \\
* \\
\end{array}$ & $\begin{array}{l}\text { Gombe } \\
\text { South }\end{array}$ & 0.603807 & 0 & $0.11^{\mathrm{ns}}$ \\
\hline $\begin{array}{l}\text { Sokoto } \\
\text { South }\end{array}$ & 1.509702 & 1 & $\begin{array}{c}0.008^{* *} \\
*\end{array}$ & $\begin{array}{l}\text { Rivers } \\
\text { South } \\
\text { East }\end{array}$ & 1.138337 & 2 & $0.02 * *$ & $\begin{array}{l}\text { Kaduna } \\
\text { South }\end{array}$ & 0.005438 & 0 & $0.456^{\mathrm{ns}}$ \\
\hline $\begin{array}{c}\text { Zamfara } \\
\text { West }\end{array}$ & 1.304532 & 1 & $\begin{array}{c}0.002^{* *} \\
*\end{array}$ & $\begin{array}{l}\text { Abia } \\
\text { South }\end{array}$ & 1.84212 & 2 & $0.01 * *$ & $\begin{array}{c}\text { Niger } \\
\text { East }\end{array}$ & $\begin{array}{c}-0.32622 \\
2 \\
\end{array}$ & 0 & $0.224^{\mathrm{ns}}$ \\
\hline $\begin{array}{l}\text { Zamfara } \\
\text { North }\end{array}$ & 1.196622 & 1 & $0.02 * *$ & $\begin{array}{c}\text { Abia } \\
\text { Central }\end{array}$ & 1.823817 & 2 & $\begin{array}{c}0.006^{* *} \\
*\end{array}$ & $\begin{array}{l}\text { Katsina } \\
\text { South }\end{array}$ & 0.389789 & 0 & $0.152^{\mathrm{ns}}$ \\
\hline $\begin{array}{l}\text { Katsina } \\
\text { Central } \\
\end{array}$ & 0.349298 & 1 & $0.042 * *$ & Imo East & 1.539762 & 2 & $0.016^{* *}$ & $\begin{array}{l}\text { Kaduna } \\
\text { Central } \\
\end{array}$ & -0.52441 & 3 & $0.036^{* *}$ \\
\hline $\begin{array}{c}\text { Zamfara } \\
\text { Central }\end{array}$ & 0.589084 & 0 & $0.06^{\mathrm{ns}}$ & Imo North & 1.137035 & 2 & $0.022 * *$ & $\begin{array}{l}\text { Kaduna } \\
\text { North }\end{array}$ & 0.176175 & 0 & $0.192^{\mathrm{ns}}$ \\
\hline $\begin{array}{l}\text { Kebbi } \\
\text { South }\end{array}$ & 1.581005 & 1 & $0.014 * *$ & $\begin{array}{l}\text { Anambra } \\
\text { North }\end{array}$ & 0.113077 & 0 & $0.446^{\mathrm{ns}}$ & $\begin{array}{l}\text { Bauchi } \\
\text { Central }\end{array}$ & 1.435214 & 1 & $\begin{array}{c}0.002^{* *} \\
*\end{array}$ \\
\hline $\begin{array}{l}\text { Niger } \\
\text { North } \\
\end{array}$ & $\begin{array}{c}-0.00819 \\
8 \\
\end{array}$ & 3 & $0.014^{* *}$ & $\begin{array}{c}\text { Anambra } \\
\text { Central } \\
\end{array}$ & 2.197321 & 0 & $0.052^{\mathrm{ns}}$ & $\begin{array}{l}\text { Kano } \\
\text { South }\end{array}$ & 0.795111 & 1 & $0.03 * *$ \\
\hline
\end{tabular}




\begin{tabular}{|c|c|c|c|c|c|c|c|c|c|c|c|}
\hline $\begin{array}{l}\text { Kwara } \\
\text { North }\end{array}$ & 1.079825 & 0 & $0.072^{\mathrm{ns}}$ & $\begin{array}{l}\text { Abia } \\
\text { North }\end{array}$ & 0.889468 & 2 & $\begin{array}{c}0.004^{* *} \\
* \\
\end{array}$ & $\begin{array}{l}\text { Katsina } \\
\text { North }\end{array}$ & 0.723859 & 0 & $0.09^{\mathrm{ns}}$ \\
\hline $\begin{array}{l}\text { Ogun } \\
\text { West }\end{array}$ & 0.463057 & 0 & $0.172^{\mathrm{ns}}$ & $\begin{array}{c}\text { Akwa Ibom } \\
\text { Northwest }\end{array}$ & 1.084156 & 2 & $\begin{array}{c}0.004 * * \\
*\end{array}$ & $\begin{array}{c}\text { Kano } \\
\text { Central }\end{array}$ & $\begin{array}{c}-0.19382 \\
1\end{array}$ & 0 & $0.148^{\mathrm{ns}}$ \\
\hline $\begin{array}{l}\text { Lagos } \\
\text { West }\end{array}$ & $\begin{array}{c}-0.33970 \\
4\end{array}$ & 0 & $0.144^{\mathrm{ns}}$ & $\begin{array}{c}\text { Akwa } \\
\text { Ibom } \\
\text { South } \\
\end{array}$ & 0.715628 & 2 & $0.028 * *$ & $\begin{array}{c}\text { Jigawa } \\
\text { Northwes } \\
\mathrm{t} \\
\end{array}$ & 1.860673 & 1 & $\begin{array}{c}0.002 * * \\
*\end{array}$ \\
\hline $\begin{array}{l}\text { Lagos } \\
\text { Central }\end{array}$ & -0.01579 & 0 & $0.486^{\mathrm{ns}}$ & $\begin{array}{c}\text { Akwa } \\
\text { Ibom } \\
\text { Northeast } \\
\end{array}$ & 0.767667 & 2 & $0.036^{* *}$ & $\begin{array}{c}\text { Jigawa } \\
\text { Southwes } \\
\mathrm{t} \\
\end{array}$ & 2.428236 & 1 & $\begin{array}{c}0.002 * * \\
*\end{array}$ \\
\hline $\begin{array}{l}\text { Lagos } \\
\text { East }\end{array}$ & 0.027419 & 0 & $0.14^{\mathrm{ns}}$ & $\begin{array}{l}\text { Cross } \\
\text { river } \\
\text { South } \\
\end{array}$ & 0.815704 & 0 & $0.068^{\mathrm{ns}}$ & $\begin{array}{c}\text { Jigawa } \\
\text { Northeast }\end{array}$ & 2.407263 & 1 & $\begin{array}{c}0.004^{* *} \\
*\end{array}$ \\
\hline $\begin{array}{l}\text { Ogun } \\
\text { Central }\end{array}$ & 0.480427 & 0 & $0.094^{\mathrm{ns}}$ & $\begin{array}{l}\text { Cross } \\
\text { river } \\
\text { Central } \\
\end{array}$ & 0.170273 & 0 & $0.302^{\mathrm{ns}}$ & $\begin{array}{l}\text { Bauchi } \\
\text { North }\end{array}$ & 2.202587 & 1 & $\begin{array}{c}0.002 * * \\
*\end{array}$ \\
\hline $\begin{array}{l}\text { Oyo } \\
\text { South }\end{array}$ & 1.352365 & 2 & $\begin{array}{c}0.006^{* *} \\
* \\
\end{array}$ & $\begin{array}{l}\text { Ebonyi } \\
\text { South }\end{array}$ & 0.312115 & 0 & $0.074^{\mathrm{ns}}$ & $\begin{array}{l}\text { Yobe } \\
\text { North }\end{array}$ & 1.530074 & 1 & $\begin{array}{c}0.002 * * \\
*\end{array}$ \\
\hline $\begin{array}{c}\text { Oyo } \\
\text { Central } \\
\end{array}$ & 1.742068 & 2 & $0.026^{* *}$ & $\begin{array}{l}\text { Enugu } \\
\text { North }\end{array}$ & 0.503644 & 2 & $\begin{array}{c}0.008^{* *} \\
* \\
\end{array}$ & $\begin{array}{l}\text { Gombe } \\
\text { North }\end{array}$ & 0.823629 & 1 & $\begin{array}{c}0.008^{* *} \\
*\end{array}$ \\
\hline $\begin{array}{l}\text { Kwara } \\
\text { Central }\end{array}$ & 0.890275 & 0 & $0.066^{\mathrm{ns}}$ & $\begin{array}{l}\text { Enugu } \\
\text { West }\end{array}$ & 0.307916 & 0 & $0.244^{\mathrm{ns}}$ & $\begin{array}{l}\text { Gombe } \\
\text { Central } \\
\end{array}$ & 0.829602 & 1 & $0.028 * *$ \\
\hline $\begin{array}{l}\text { Kwara } \\
\text { South }\end{array}$ & 0.721746 & 0 & $0.092^{\mathrm{ns}}$ & $\begin{array}{l}\text { Enugu } \\
\text { East }\end{array}$ & 0.543905 & 0 & $0.186^{\mathrm{ns}}$ & $\begin{array}{l}\text { Adamawa } \\
\text { South }\end{array}$ & 0.456606 & 0 & $0.212^{\mathrm{ns}}$ \\
\hline $\begin{array}{l}\text { Osun } \\
\text { West }\end{array}$ & 0.933906 & 2 & $\begin{array}{c}0.008^{* *} \\
* \\
\end{array}$ & $\begin{array}{l}\text { Ebonyi } \\
\text { Central } \\
\end{array}$ & 0.213703 & 0 & $0.096^{\mathrm{ns}}$ & $\begin{array}{c}\text { Adamawa } \\
\text { Central }\end{array}$ & 0.143101 & 0 & $0.072^{\mathrm{ns}}$ \\
\hline $\begin{array}{c}\text { Osun } \\
\text { East } \\
\end{array}$ & 0.90421 & 2 & $\begin{array}{c}0.028^{* *} \\
* \\
\end{array}$ & $\begin{array}{l}\text { Ebonyi } \\
\text { North }\end{array}$ & $\begin{array}{c}-0.20927 \\
8 \\
\end{array}$ & 0 & $0.338^{\mathrm{ns}}$ & $\begin{array}{l}\text { Adamawa } \\
\text { North }\end{array}$ & 0.093192 & 0 & $0.418^{\mathrm{ns}}$ \\
\hline $\begin{array}{l}\text { Ogun } \\
\text { East }\end{array}$ & 1.112751 & 2 & $\begin{array}{c}0.004^{* *} \\
*\end{array}$ & $\begin{array}{l}\text { Cross } \\
\text { river } \\
\text { North } \\
\end{array}$ & $\begin{array}{c}-0.25419 \\
7\end{array}$ & 0 & $0.286^{\mathrm{ns}}$ & $\begin{array}{l}\text { Yobe } \\
\text { South }\end{array}$ & 1.336898 & 1 & $0.012 * *$ \\
\hline $\begin{array}{l}\text { Ekiti } \\
\text { South }\end{array}$ & 0.279504 & 0 & $0.18^{\mathrm{ns}}$ & Kogi East & 0.198294 & 0 & $0.34^{\mathrm{ns}}$ & Yobe East & 1.134799 & 1 & $0.01 * *$ \\
\hline $\begin{array}{l}\text { Senatoria } \\
1 \text { Districts }\end{array}$ & $\begin{array}{l}\text { LISA } \\
\text { Indices }\end{array}$ & $\begin{array}{l}\text { Cluste } \\
\text { r Type }\end{array}$ & $P$ - Value & $\begin{array}{c}\text { Senatorial } \\
\text { Districts }\end{array}$ & $\begin{array}{c}\text { LISA } \\
\text { Indices }\end{array}$ & $\begin{array}{l}\text { Cluste } \\
\text { r Type }\end{array}$ & P - Value & $\begin{array}{l}\text { Senatorial } \\
\text { Districts }\end{array}$ & $\begin{array}{c}\text { LISA } \\
\text { Indices }\end{array}$ & $\begin{array}{l}\text { Cluste } \\
\text { r Type }\end{array}$ & P - Value \\
\hline $\begin{array}{c}\text { Ondo } \\
\text { Central } \\
\end{array}$ & 0.582487 & 2 & $0.014 * *$ & $\begin{array}{l}\text { Benue } \\
\text { South }\end{array}$ & $\begin{array}{c}-0.03422 \\
6 \\
\end{array}$ & 0 & $0.426^{\mathrm{ns}}$ & $\begin{array}{l}\text { Borno } \\
\text { North } \\
\end{array}$ & 0.383302 & 0 & $0.332^{\text {ns }}$ \\
\hline $\begin{array}{l}\text { Ondo } \\
\text { North }\end{array}$ & 0.127022 & 0 & $0.216^{\mathrm{ns}}$ & $\begin{array}{c}\text { Benue } \\
\text { Northeast }\end{array}$ & $\begin{array}{c}-0.05224 \\
6 \\
\end{array}$ & 0 & $0.2^{\mathrm{ns}}$ & $\begin{array}{l}\text { Borno } \\
\text { South }\end{array}$ & 0.113653 & 1 & $0.028^{* *}$ \\
\hline $\begin{array}{l}\text { Kogi } \\
\text { West }\end{array}$ & 0.417307 & 0 & $0.126^{\mathrm{ns}}$ & $\begin{array}{c}\text { Benue } \\
\text { Northwest }\end{array}$ & $\begin{array}{c}-0.02907 \\
4 \\
\end{array}$ & 0 & $0.372^{\mathrm{ns}}$ & $\begin{array}{c}\text { Ekiti } \\
\text { Central }\end{array}$ & 0.343983 & 2 & $0.042 * *$ \\
\hline $\begin{array}{l}\text { Kogi } \\
\text { West }\end{array}$ & 0.417307 & 0 & 0.126 & $\begin{array}{c}\text { Benue } \\
\text { Northwest }\end{array}$ & $\begin{array}{c}-0.02907 \\
4 \\
\end{array}$ & 0 & 0.372 & $\begin{array}{c}\text { Ekiti } \\
\text { Central }\end{array}$ & 0.343983 & 2 & $0.042 * *$ \\
\hline $\begin{array}{c}\text { Kogi } \\
\text { Central } \\
\end{array}$ & 0.946763 & 0 & 0.064 & $\begin{array}{l}\text { Taraba } \\
\text { Central } \\
\end{array}$ & 0.084992 & 0 & 0.148 & $\begin{array}{c}\text { Ekiti } \\
\text { North } \\
\end{array}$ & $\begin{array}{c}-0.12929 \\
4 \\
\end{array}$ & 0 & 0.34 \\
\hline $\begin{array}{c}\text { Edo } \\
\text { North }\end{array}$ & $\begin{array}{c}-0.06272 \\
2 \\
\end{array}$ & 0 & 0.292 & $\begin{array}{l}\text { Taraba } \\
\text { South }\end{array}$ & 0.073737 & 0 & 0.366 & $\begin{array}{l}\text { Anambra } \\
\text { South }\end{array}$ & 1.433544 & 2 & $0.026^{* *}$ \\
\hline $\begin{array}{c}\text { Edo } \\
\text { South }\end{array}$ & 0.455539 & 0 & 0.192 & $\begin{array}{l}\text { Niger } \\
\text { South }\end{array}$ & $\begin{array}{c}-0.15267 \\
1 \\
\end{array}$ & 0 & 0.08 & $\begin{array}{c}\text { Kano } \\
\text { North } \\
\end{array}$ & 0 & 3 & $\begin{array}{c}0.002^{* *} \\
* \\
\end{array}$ \\
\hline $\begin{array}{c}\text { Edo } \\
\text { Central } \\
\end{array}$ & $\begin{array}{c}-0.15622 \\
1 \\
\end{array}$ & 0 & 0.318 & Abuja & $\begin{array}{c}-0.27887 \\
4 \\
\end{array}$ & 0 & 0.128 & $\begin{array}{l}\text { Oyo } \\
\text { North } \\
\end{array}$ & 0 & 3 & $\begin{array}{c}0.002 * * \\
*\end{array}$ \\
\hline $\begin{array}{c}\text { Delta } \\
\text { North }\end{array}$ & 0.567632 & 2 & $0.022 * *$ & $\begin{array}{l}\text { Nassaraw } \\
\text { a Central } \\
\end{array}$ & 0.157945 & 0 & 0.148 & $\begin{array}{c}\text { Osun } \\
\text { Central }\end{array}$ & 0.035184 & 0 & 0.428 \\
\hline $\begin{array}{c}\text { Delta } \\
\text { Central } \\
\end{array}$ & 0.220928 & 0 & 0.136 & $\begin{array}{l}\text { Nassaraw } \\
\text { a North }\end{array}$ & 0.030504 & 0 & 0.358 & Ondo & 0.517628 & 2 & $0.02^{* * *}$ \\
\hline \multirow[t]{2}{*}{$\begin{array}{c}\text { Bayelsa } \\
\text { West }\end{array}$} & 1.832168 & 2 & $0.044^{* *}$ & $\begin{array}{l}\text { Nassaraw } \\
\text { a South }\end{array}$ & 0.030894 & 0 & 0.26 & $\begin{array}{l}\text { Plateau } \\
\text { North }\end{array}$ & $\begin{array}{c}-0.00895 \\
7 \\
\end{array}$ & 0 & 0.178 \\
\hline & & & & & & & & $\begin{array}{l}\text { Delta } \\
\text { South }\end{array}$ & 0.309415 & 2 & $\begin{array}{c}0.008^{* *} \\
*\end{array}$ \\
\hline
\end{tabular}

Source: Result of Data Analyzed (2009)

Note: ${ }^{* *}$ p-value $<0.01$ and $* *$ p-value $<0.05$, ns means not significant, $1=\mathrm{HH}, 2=\mathrm{LL}$ and $3=\mathrm{LH}$ (Geoda $0.9 .5 i$ reports only the significant clusters)

\section{Conclusions and Recommendations}

The application of spatial data analysis methods revealed strong evidence of spatial interaction across senatorial district boundaries. Using a binary weight matrix in the estimation of spatial effects, we found that proximity to senatorial districts that have a high (low) poverty rate will 
increase the probability that household in a senatorial district will its elf have a high (low) incidence of poverty.

The landscape of poverty incidence obtained from the study identified the hot spots and cold spots of poverty in Nigeria. Knowing precisely where concentrations and isolated islands of poverty exist will help various government owned organizations with the mandate of allev iating poverty (NAPEP, NEPAD and NEEDS) and state governments in their continuing challenge of combating this fundamental threat to well-being and economic development of Nigeria. Moreover, this finding will assist government agencies saddled with poverty alleviation in applying specific strategy to different landscape of poverty. Also, the elected representatives (senators) are afforded the opportunity of knowing the poverty landscape of their respective senatorial districts so that their constituency development fund can be property channeled to poverty alleviation.

\section{ACKNOWLEDGEMENTS}

The authors are thankful to Dr. Julia Koschinsky (Assistant Research Professor \& Research Director of GeoDa Center, Arizona State University, Tempe, AZ, 85287, United States) for her technical assistance.

\section{REFERENCES}

[1] United Nations Development Programme (UNDP), Nigeria Human Development Report. Millennium Edition, Lagos, 2005.

[2] National Bureau of Statistics (NBS), Poverty Profile for Nigeria. Federal Republic of Nigeria, 2005.

[3] International Monetary Fund (IMF), "National Economic Empowerment and Development Strategy (NEEDS)", Nigeria Poverty Reduction Strategy Paper. IMF Country Report. No. 05/433, 2005.

[4] V. O. Akinyosoye, Government and Agriculture in Nigeria: Analysis of Policies, Programmes and Administration. Macmillan Publishers Limited: Lagos, Nigeria, 2005.

[5] Rupasingha, S. J. Goetz, "Social and Political Forces as Determinants of Poverty: A Spatial Analysis." The Journal of Socio-Economic, vol. 36. pp. 650-671, 2007.

[6] D. Cliff, J. K. Ord, Spatial Autocorrelation, Pion Limited, London, England, 1973.

[7] Getis, J. K. Ord, "The Analysis of Spatial Association by use of Distance Statistics", Geo graphical Analy sis, vol. 24, pp. 189-206, 1992.

[8] L. Anselin, "Local Indicators of Spatial Association-LISA". Geographical Analysis, vol. 27, pp. $93-115,1995$.

[9] L. Anselin, GeoDa ${ }^{\mathrm{TM}}$ 0.9.5-i Release Notes, Center for Spatially Integrated Social Science, 2004.
[10] L. Anselin, Exploring Spatial Data with GeoDaTM : A Workbook, Spatial Analysis Laboratory, Department of Geography, University of Illinois, Urbana-Champaign, Urbana, IL 61801, 2005.

[11] Z. Guilmoto, S. Oliveau, "Spatial Regression and Determinants of Juvenile Sex Ratio in India", A paper Presented at the Seminar on Female Deficit in Asia: Trends and Perspectives, Singapore, 5-7 December, 2005.

[12] L. Anselin, "Local Indicators of Spatial Association LISA”, Geographical Analy sis, vol. 27, pp. 93-115, 1995.

[13] L. Anselin,The Moran Scatterplot as an ESDA Tool to Assess Local Instability in Spatial Association, in M. Fischer, H. J. Scholten, D. Unwin (Eds.), Spatial analytical perspectives on GIS (pp. 111-125). Taylor \& Frances, London, England, 1996.

[14] P. R. Voss, D. D. Long, B. H. Roger, S. Friedman, "County Child Poverty Rates in the US: A Spatial Regression Approach”, Popul Res Policy Rev, no. 25,pp. 369-391, 2006.

[15] L. Anselin, Spatial Econometrics: Methods and Models, Kluwer Academic Publishers, The Netherlands, 1988.

[16] L. Anselin, "Rao's Score Test in Spatial Econometrics", Journal of Statistical Planning and Inference, vol. 97, pp.113-139. 2001a.

[17] L. Anselin, A. K. Bera, Spatial Dependence Linear in Regression Models With an Introduction to Spatial Econometrics, in A. Ullah, D. A. Giles (Eds.), Handbook of Applied Economic Statistics (pp. 237-289), Marcel Dekker, New York, USA, 1998.

[18] N. Minot, B. Baulch, "Poverty and Inequality in Vietnam: Spatial Patterns and Geographic Determinants". Inter-M inisterial Poverty Mapping Task Force. International Food Policy Research Institute (IFPRI) and Institute of Development Studies, 2003.

[19] L. Anselin, "Under the hood: Issues in the Specification and Interpretation of Spatial Regression Models." Agricultural Economics, vol. 27, pp. 247-267, 2002.

[20] J. B. Holt, "The Topography of Poverty in the United States: A Spatial Analysis Using County-Level Data", Prevention of Chronic Disease, vol. 4, no. 4, 2007.

[21] Petrucci, N. Salvati, C. Seghieri, "The Application of a Spatial Regression Model to the Analysis of Mapping of Poverty." Environmental and Natural Resource Services, Sustainable Development Department. Working Paper Series No. 7. Food and A griculture Organization (FAO) of the United Nations, 2003.

[22] U. Amarasinghe, M. Samad, M. Anputhas, "Spatial Clustering of Rural Poverty and Food Insecurity in Sri Lanka." International Water Management Institute, 127, Sunil Mawatha, Pelawatta, Battaramulla, Colombo, Sri Lanka, 2004.

[23] M. S. Crandall, B. A. Weber, "Local Social and Economic Conditions, Spatial Concentrations of Poverty, and Poverty Dynamics". American Journal of Agricultural Economics, 2004.

[24] D. Cliff, J. K. Ord, Spatial Processes: Models and Applications, Pion Limited, London, England, 1981. 
[25] P. Moran, "A Test for the Serial Dependence of Residuals", Biometrika, vol. 37, pp. 178-181, 1950.

[26] T. C. Bailey, A. C. Gatrell, Interactive Spatial Data Analysis, Addison Wesley Longman Limited, Harlow, England, 1995.

[27] A. Griffith, Spatial Autocorrelation and Spatial Filtering: Gaining Understanding through Theory and Scientific Visualization, Springer, Berlin, Germany, 2003.
[28] S. Thomas, S. Canagarajah, "Poverty in a Wealthy Economy: The Case of Nigeria", International Monetary Fund (IMF) Working Paper, 2002.

[29] T. Benson, “Application of Poverty Mapping to World Food Programme Activities in Malawi", International Food Policy Research Institute, Washington DC, USA, (2004). 